DOI 10.15290/cnisk.2021.01.10.12

\author{
ANNA PENKAŁA-JASTRZĘBSKA \\ https://orcid.org/0000-0001-6386-8139 \\ Uniwersytet Pedagogiczny im. Komisji Edukacji Narodowej w Krakowie
}

\title{
Janusz Antoni Wiśniowiecki, Ilias Polski, wyd. Przemysław P. Romaniuk, Jacek Burdowicz- -Nowicki, (Warszawa: Wydawnictwo Neriton, 2018), ISBN 978-83-660118-01-3
}

Wydania niepublikowanych wcześniej materiałów źródłowych zawsze spotykaja się $z$ ogromnym zainteresowaniem $\mathrm{w}$ środowisku historyków. Nie inaczej stało się w przypadku przygotowanej edycji odnalezionego w 2015 r. oryginału dzieła Ilias Polski autorstwa Janusza Antoniego Wiśniowieckiego (zm. 1741). Wydany materiał jest tym cenniejszy, że dotyczy okresu szczególnego - lat 1700-1710, a więc czasów wielkiej wojny północnej. Wydarzenia te, widziane $z$ perspektywy uczestnika opisywanych zdarzeń, postaci bezpośrednio w nie zaangażowanej, a jednocześnie doskonale obeznanej w ówczesnych realiach politycznych, stanowią niezwykle cenny materiał badawczy o dużym znaczeniu dla badaczy epoki.

Janusz Antoni, syn wojewody bracławskiego Konstantego Krzysztofa Wiśniowieckiego (zm. 1686) i Anny z Chodorowskich, żonaty z zamożną Teofilą $z$ Leszczyńskich, dzięki doskonałej protekcji krewnych i koligatów szybko włączył się aktywnie w życie polityczne w Rzeczypospolitej. Już w 1699 r. zdołał wejść do senatu jako marszałek nadworny litewski. W 1702 r. sięgną po urząd kasztelana wileńskiego, ustępując $z$ marszałkostwa na rzecz brata - Micha- 
ła Serwacego Wiśniowieckiego (zm. 1744). Na tym jednak kariera polityczna Janusza Antoniego Wiśniowieckiego się nie zatrzymała - już dwa lata później zdołał bowiem pozyskać nominację na wojewodę wileńskiego. W okresie wojny północnej Wiśniowiecki dał się poznać jako wierny sojusznik króla Augusta II. W kolejnych latach autor dzieła Ilias Polski oddalał się jednak od stronnictwa popierającego Wettina. Jako królewski opozycjonista w 1715 r. odegrał aktywna rolę w zawiazaniu konfederacji tarnogrodzkiej. Dzięki amnestii, jaka objęto członków konfederacji, a także pojednaniu ze stroną rosyjską Janusz Antoni zdołał jednak uratować swoja karierę w Rzeczypospolitej. W 1726 r. otrzymał nominację na urząd kasztelana krakowskiego i do końca życia odgrywał w Rzeczypospolitej znaczącą rolę polityczna, myśląc nawet o przejęciu korony po śmierci Augusta II.

Recenzowane wydanie źródłowe poprzedza obszerny wstęp, w którym skrupulatnie nakreślone zostały zarówno okoliczności polityczne opisywanych wydarzeń, jak i aspekty związane $z$ odnalezieniem i udostępnieniem materiału źródłowego. Autorzy wydania zwięźle przybliżyli postać samego Janusza Antoniego Wiśniowieckiego, szczególny nacisk kładąc na zarysowanie roli, jaką odgrywał on w Rzeczypospolitej w okresie, który obejmuje wydanie źródłowe. Wartościowe sa także wzmianki dotyczące zarówno okoliczności odnalezienia materiału, który stał się przedmiotem edycji źródłowej, jak i przybliżenie zakresu działań podjętych wcześniej na rzecz upowszechnienia wskazanych materiałów. Jednoznacznie wyjaśniono też złożoną i problematyczną kwestię autorstwa omawianego dzieła.

Ilias Polski wydany został w układzie chronologicznym, $z$ dokładnym wydzieleniem poszczególnych lat, począwszy od roku 1700, a skończywszy na roku 1710. Całość poprzedza krótkie wprowadzenie autorstwa samego Wiśniowieckiego. Autorzy dokładnie wyjaśnili zasady przyjęte w zakresie edycji źródła, podobnie jak metody opracowania przypisów wyjaśniających problematyczne kwestie. Całość wydania została uzupełniona cenna wskazówką dla badaczy w postaci słownika wyrazów staropolskich. Zgromadzenie i wyjaśnienie problematycznych pojęć stanowi cenną wskazówkę dla badaczy epoki co do sposobu interpretacji wielu terminów dawnych. Korzystanie z przygotowanych materiałów znacznie ułatwia też indeks osobowy, umieszczony na końcu recenzowanego wydania.

Autor dzieła, choć przedmiotem swej relacji obją lata 17001710, chętnie odwoływał się do wydarzeń poprzedzających okres 
wojny północnej. Przywoływał przede wszystkim te osoby i zdarzenia, których aktywność wpłynęła zarówno na przebieg elekcji po śmierci Jana III Sobieskiego, jak i na późniejsze rozstrzygnięcia polityczne. W kontekście badań nad historia kobiet wskazany materiał dostarcza ciekawych ustaleń o charakterze biograficznym, a także rozszerza kontekst znanych już wydarzeń o kwestie ich społecznego odbioru i funkcjonowania relacji personalnych. Interesujący jest również wydźwięk działan podejmowanych przez kobiety, podobnie jak i ich ocena przez osoby postronne. Wiśniowiecki chętnie kreślił sylwetki wspominanych w dziele osób, zwracając uwagę na ich wpływy, utrzymywane relacje, a także motywacje podejmowanych działań.

Specyficzne dla omawianego źródła jest to, że Wiśniowiecki w niewielu miejscach odwoływał się do spraw własnej familii. Spośród kręgu rodzinnego ze znaczących postaci wyeksponował przede wszystkim osobe swej matki, Anny z Chodorowskich $1^{\circ}$ voto Wiśniowieckiej, $2^{\circ}$ voto Dolskiej. Janusz Antoni z nieukrywaną sympatia odnosił się do drugiego męża Anny - Jana Karola Dolskiego (zm. 1695), marszałka wielkiego litewskiego, którego określał jako „zacnego pana, którego afektów dotąd syty umysł nie powinien ina-

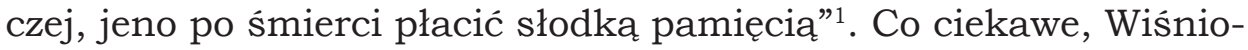
wiecki wspominał również o nieznanym dotychczas epizodzie $z$ jej $\dot{z}$ ycia ${ }^{2}$, podajac, że po śmierci Dolskiego matka rozważała opcję kolejnego zamążpójścia ${ }^{3}$. Rozpatrywanym przez nią kandydatem miał być również świeżo owdowiały Kazimierz Jan Sapieha (zm. 1720). $Z$ planów tych jednak nic nie wyszło. Sapieha rzeczywiście żenił się jeszcze dwukrotnie, jednakże jego wybrankami zostawały kolejno Teresa $z$ Gosiewskich i Antonina Sybilla $z$ Waldsteinów (wdowa po Andrzeju Kazimierzu Giełgudzie, zm. 1711, pisarzu wielkim litewskim).

\footnotetext{
1 Janusz Antoni Wiśniowiecki, Ilias Polski, Przemysław P. Romaniuk, Jacek Burdowicz-Nowicki (wyd.), (Warszawa: Wydawnictwo Neriton, 2018), 71.

2 Najszersze $z$ dotychczasowych ustaleń biograficznych znajdziemy w: Agnieszka Słaby, „»Aby po śmierci jakowa trudność na potem nie zachodziła« - testament marszałkowej Anny z Chodorowskich 1 v. Wiśniowieckiej Dolskiej”, Klio. Czasopismo poświęcone dziejom Polski i powszechnym, t. 50, z. 3, 2019, 131-148. Dodatkowe ustalenia dotyczące aktywności magnatki: Rafał Jankowski, „Sprawa testamentów Anny z Chodorowskich Dolskiej z 1711 roku”, Miscellanea Historico-Archivistica, t. 21, 2014, 273-282; Bożena Popiołek, Kobiecy świat w czasach Augusta II. Studia nad mentalnościa kobiet z kręgów szlacheckich, (Kraków: Wydawnictwo Naukowe Akademii Pedagogicznej im. KEN w Krakowie, 2003), 302.

3 Jest to o tyle ciekawe, że w prywatnej korespondencji $z$ tego okresu Dolska skupiała się przede wszystkim na zapewnieniu sobie protekcji w obliczu śmierci współmałżonka. Archiwum Główne Akt Dawnych, Archiwum Warszawskie Radziwiłłów, dział V, nr 3129, Listy Anny z Chodorowskich Dolskiej do Karola Stanisława Radziwiłła, 1-6.
} 
Wiśniowiecki lakonicznie wspominał natomiast o swych własnych planach małżeńskich. Podał jedynie, że już w 1700 r. wraz $z$ matką sondowali szanse na dobry ożenek, udając się wspólnie do Lwowa. Starania te miały im przynieść koligację z Teresą Katarzyną Lubomirską (zm. 1712), córką marszałka wielkiego koronnego Józefa Karola Lubomirskiego ${ }^{4}$. $Z$ tego projektu nic jednak nie wyszło. O niepowodzeniu wskazanego projektu Wiśniowiecki pisał zdawkowo, podając jedynie „wyrok chcącego prowadzi, opierającego się ciagnie, bo $z$ drogi pomienionej wrócić się musiał"5. Ostatecznie, w 1704 r., Wiśniowiecki ożenił się z Teofilą z Leszczyńskich. Warto jedynie dodać, że dzięki staraniom matki Teofili - Ludwiki z Zasławskich - sama Teresa $z$ Lubomirskich została już w 1701 r. wydana za wdowca Karola III Filipa Wittelsbacha (zm. 1742), elektora palatynatu reńskiego i księcia neuburskiego (żonatego wcześniej z Ludwiką Karoliną z Radziwiłłów, zm. 1695).

Odchodzac od kwestii familijnych, autor Iliasa Polski swe zainteresowanie kierował raczej w stronę głośnych spraw obyczajowych. Wprawdzie nie były one związane $z$ sama wojna północna, jednak najwyraźniej absorbowały wówczas opinię publiczną. W kontekście aktywności kobiecej autor Iliasa Polski przypomniał m.in. kwestię drugiego małżeństwa Ludwiki Karoliny z Radziwiłłów (zm. 1695), koniuszanki litewskiej, wdowy po Ludwiku Leopoldzie Hohenzollernie (zm. 1687), synu elektora Fryderyka Wilhelma ${ }^{6}$. Wiśniowiecki wspomniał o nieudolnych zabiegach o rękę wdowy, podjętych przez królewskiego syna Jakuba Ludwika Sobieskiego ${ }^{7}$,

\footnotetext{
4 Zob. Adam Przyboś, „Lubomirski Józef Karol”, w: Polski Słownik Biograficzny (dalej: PSB), t. 18, Wrocław: Zakład Narodowy im. Ossolińskich, 1973), 27.

5 Janusz Antoni Wiśniowiecki, Ilias Polski, 74.

6 Elżbieta Bagińska, „Spór o Ludwikę Karolinę Radziwiłłównę”, Białostocczyzna, nr 4/48, 1997, 3-14; Antoni Zygmunt Helcel, O dwukrotnem zamęzciu Xiężniczki Ludwiki Karoliny Radziwiłłownej $i$ wynikłych ztąd $w$ Polsce zamieszkach. Przyczynek do dziejów panowania Jana III, Kraków 1857, 21-26; Urszula Augustyniak, „Instrukcja Bogusława Radziwiłła dla opiekunów jego córki, Ludwiki Karoliny (Przyczynek do edukacji młodej ewangeliczki $w$ końcu XVII wieku”, Odrodzenie i Reformacja w Polsce. Materiały, t. 36, 1992, 215-235; Theodor Schiemann, „Luise Charlotte Radziwill, Markgräfin von Brandenburg”, w: R. Hoser (red.), Forschungen zur Brandenburgischen und Preussischen Geschichte, Bd. 3, (Leipzig: De Gruyter, 1890), 125-168; Jerzy Lesiński, „Spory o dobra neuburskie”, Miscellanea Historico-Archivistica, t. 4, 1996, 95-132; Alojzy Sajkowski, Staropolska miłość: z dawnych listów i pamiętników, (Poznań: Wydawnictwo Poznańskie, 1981), 133-135; Zbigniew Wójcik, Jan III Sobieski 1629-1696, (Warszawa: Państwowy Instytut Wydawniczy, 1983), 454-455.

7 Aleksander Wejnert, Szczegóły wyświecajace powody zerwania umów małżeńskich królewica Jakóba Sobieskiego z księżna Radziwiłłowa Brandenburgską, (Warszawa, 1855), [online] [dostęp: 24.07.2021]. Dostępny w World Wide Web: <https://polona.pl/item/szcze-
} 
a także późniejszych próbach przejęcia dóbr neuburskich ${ }^{8}$. Kwestie te zostały wyeksponowane w kontekście rozważań nad przyczynami wzrostu frakcji magnackich w Rzeczypospolitej. Należy zwrócić uwagę, że przywołując kwestie nieudolnych zabiegów Sobieskiego o rękę Radziwiłłówny, Wiśniowiecki sugerował, że to właśnie poszukiwanie przez Jana III sojuszników gotowych poprzeć jego rację w sporze o dobra neuburskie przekuło się przede wszystkim na polityczny sukces Sapiehów ${ }^{9}$. W komentarzu przygotowanym przez wydawców zabrakło jednak wyjaśnienia, że godząc się na propozycję małżeństwa wysunięta przez Hohenzollerna Ludwika Karolina nie tylko złamała porozumienie $\mathrm{z}$ królewiczem Jakubem, ale też w sposób bezpośredni naruszyła interesy króla Jana III Sobieskiego. Ten bowiem, łudzony szansa zawarcia związku $z$ Radziwiłłówna przez swego syna Jakuba, zgodził się wcześniej na potwierdzenie praw Hohenzollernów co do ich władzy w Prusach. Sprawa zaś dóbr neuburskich miała absorbować Radziwiłłów do połowy XVIII w. ${ }^{10}$

Należy jednak zauważyć, że spraw o podobnym znaczeniu w dziele pojawia się niewiele. Autor Iliasa Polski nie stronił natomiast od przywoływania kwestii o znacznie mniejszym znaczeniu, interesujących jednak $z$ uwagi na swój charakter obyczajowy. Jedna $z$ takich kwestii, przywołana jakby mimochodem, była plotka dotycząca relacji uczuciowych utrzymywanych przez prymasa Radziejowskiego $z$ wojewodziną łęczycka Konstancja $z$ Niszczyckich Towiańska. Owocem ich związku miał być Krzysztof Mikołaj Towiański (zm. 1761), podczaszy koronny. Wiśniowiecki zapisał, że Radziejowski Towiańska „serdecznie kochał”, co w jego przypad$\mathrm{ku}$ „ćmiło te wielkie i heroiczne cnoty” ${ }^{11}$. Wydawcy konsekwentnie zdecydowali się podawać jedynie informacje o „prymasie Radziejowskim" [s. 100-101], nie doprecyzowując, że chodziło o Michała Stefana Radziejowskiego (zm. 1705), podkanclerzego koronnego, kardynała i prymasa Polski. Rozważania samego Wiśniowieckiego

goly-wyswiecajace-powody-zerwania-umow-malzenskich-krolewica-jakoba-sobieskiego -z,Njc4NzIOMDE/2/\#info:metadata>; Stanisław Tarnowski, „Tajemnica roku 1688”, Rocznik Akademii Umiejętności, 1883, 233-251.

8 Andrzej Kamieński, „Polityka brandenburska Jana III Sobieskiego”, Zeszyty Naukowe Uniwersytetu Jagiellońskiego. Prace Historyczne, nr 146, z. 2, 2019, 313-316; Jerzy Lesiński, „Spory o dobra”, 95-132.

9 Janusz Antoni Wiśniowiecki, Ilias Polski, 68.

10 Zbigniew Anusik, Andrzej Stroynowski, „Radziwiłłowie w epoce saskiej. Zarys dziejów politycznych i majątkowych", Acta Universitatis Lodziensis. Folia Historica, nr 33, 1989, 29-58.

11 Janusz Antoni Wiśniowiecki, Mlias Polski, 101. 
odnośnie do sercowych relacji Radziejowskiego szły jednak znacznie dalej. Autor Iliasa wnioskował bowiem, że Towiańska wywierała ogromny wpływ na prymasa, swoimi ambicjami wpędzając go w niemałe problemy. W dziele znalazło się zreszta wskazanie, że relacja ta była utrzymywana, choć, jak zaznaczył Wiśniowiecki ,ja to wiem, że była jego krewna” 12 . Problem ten nie został jednak doprecyzowany i wyjaśniony przez wydawców. Przyczyną zaś skandalu obyczajowego był nie tylko fakt utrzymywania relacji miłosnej Radziejowskiego $z$ Towiańska, ale też kwestia ich pokrewieństwa. Towiańska była bowiem kuzynka rozwiąłego prymasa. Co więcej, zmarły w $1705 \mathrm{r}$. Radziejowski na mocy testamentu zostawił zarówno kochance, jak i Krzysztofowi Mikołajowi Towiańskiemu ogromny majątek ${ }^{13}$.

Nie był to jedyny skandal obyczajowy, o jakim wspominał Wiśniowiecki. Wymieniając zalety i osiagnięcia Hieronima Augustyna Lubomirskiego (zm. 1706), podskarbiego wielkiego koronnego, wypomniał mu małżeństwo $z$ Konstancją $z$ Bokumów (zm. 1707). Lubomirski wszedł $\mathrm{w}$ ten zwiazek pomimo wcześniejszych ślubów zakonnych, które złożył jako kawaler maltański ${ }^{14}$. Janusz Antoni ocenił, że w jego wypadku było to „mniej potrzebne z pasji ożenienie”15. W komentarzu do wydania nie wspomniano jednak o zaangażowaniu w całe przedsięwzięcie króla Jana III Sobieskiego oraz o tym, że nie bez znaczenia były w tym wypadku także koneksje rodzinne panny. Brat Konstancji - Jan Kazimierz Bokum (zm. 1721) był bowiem królewskim sekretarzem. W samym materiale źródłowym znalazły się natomiast odniesienia wskazujące na okoliczności połączenia obu wskazanych wyżej rodzin, co dokonało się poprzez małżeństwo Krzysztofa Mikołaja Towiańskiego i Marianny z Lubomirskich (córki Hieronima Augustyna i Konstancji z Bokumów) ${ }^{16}$. Wydarzenie to sam Wiśniowiecki podsumował trafną sentencja „Znaczne wesele, a któż tego nie wi, Tak bowiem państwo jest de tribu Levi”, odwołując się tym samym zarówno do pogłosek o pochodzeniu Towiańskiego, jak i przypominając ślubowania złożone przez Hieronima Augustyna ${ }^{17}$.

\footnotetext{
12 Ibidem, 101.

13 Biblioteka Narodowa, SD W 1/2995, Testamentum cardinalis Radzieiowskii primatis Regni Poloniae et M.D. Lithuaniae datum Dantisci die 12 Octobris anno 1705, 15-16.

14 Tadeusz W. Lange, „Maltański epizod księcia Hieronima Lubomirskiego”, LIMES. Studia i Materiały z Dziejów Europy Środkowo-Wschodniej, nr 3-4, 2010-2011, 14.

15 Janusz Antoni Wiśniowiecki, Ilias Polski, 114.

16 Ibidem, 161.

17 Ibidem.
} 
Przedmiotem plotek i domysłów były też relacje $z$ kobietami utrzymywane przez samego króla Augusta II. W miłostkach Wettina Wiśniowiecki upatrywał przyczyn jego przedłużającej się rezydencji w Dreźnie i braku należytego skupienia się na sprawach Rzeczypospolitej ${ }^{18}$. W tym kontekście rozpatrywał m.in. romans Augusta II $z$ Urszulą Katarzyną z Bokumów Lubomirską. Król doczekał się $z$ nią potomstwa, jednakże nie tylko - jak sugerowali wydawcy dzieła - syna Jana Jerzego, ale też córki ${ }^{19}$. Autorzy wydania w przypisie nieco mylnie posługują się też określeniem „Urszula Lubomirska”, sugerujacym jakoby panna pochodziła $z$ rodziny Lubomirskich [s. 184]. Tymczasem była ona przecież córka spolonizowanego Johanna Heinricha von Altenbockum (zm. 1685) i Konstancji Tekli Branickiej, siostrą wspomnianej wyżej Konstancji z Bokumów Lubomirskiej, a od 1695 r. żoną podstolego koronnego Jerzego Dominika Lubomirskiego (zm. 1727). Wiśniowiecki sporadycznie wspominał, jak dużą rolę polityczną w Rzeczypospolitej odgrywały niektóre $z$ polskich pań, umiejętnie wpływając na obsadę urzędów i kariere polityczną swych krewnych i koligatów. Do grupy szczególnie wpływowych kobiet początku XVIII w. zaliczał on właśnie Urszulę Katarzynę. Dzięki nawiązaniu relacji uczuciowej z królem Augustem II zyskała ona pewien wpływ na politykę prowadzona przez Wettina w Rzeczypospolitej ${ }^{20}$. Wiśniowiecki wnioskował, że to przede wszystkim dzięki zaangażowaniu wpływowej żony Lubomirski został mianowany podkomorzym koronnym ${ }^{21}$. Zakończenie romansu przez króla mocno odcisnęło się na kondycji zdrowotnej Urszuli Katarzyny. Pomocy szukała ona u krewnej swego męża - wojewodziny bełskiej Elżbiety z Lubomirskich Sieniawskiej (zm. 1729). Autor Iliasa Polski sugerował nawet, że Sieniawska starała się użyć swoich wpływów, aby przywrócić koligatkę do królewskiej łaski²2. Ustalenia te w nieco innym świetle ukazują aktywność samej Sieniawskiej. Dotychczas bowiem wnioskowano, że wojewodzina była bardzo zachowawcza w swych posunięciach, usiłując nawet ukryć

\footnotetext{
18 Ibidem, 184.

19 Bożena Popiołek, Królowa bez korony. Studium z życia i działalności Elżbiety z Lubomirskich Sieniawskiej ok. 1669-1729, (Kraków: Wydawnictwo Naukowe Wyższej Szkoły Pedagogicznej, 1996), 41.

20 Zob. Heinrich Theodor Flathe, „Lubomirska Ursula Katharina Fürstin von”, w: Allgemeine Deutsche Biographie, t. 19, (Leipzig: Duncker \& Humblot, 1884), 333-334.

21 Janusz Antoni Wiśniowiecki, Ilias Polski, 109.

22 Ibidem, 208.
} 
swe kontakty $z$ Lubomirska przed najbliższymi krewnymi ${ }^{23}$. Warto też zaznaczyć, że zarówno relacja z królem, jak i przedłużające się okresy nieobecności Urszuli Katarzyny, dotąd doskonale czującej się na dworze drezdeńskim, wpłynęły na rozpad więzi między małżonkami. Lubomirski miał czuć się rozczarowany relacjami z małżonką jako „niewdzięczną afektów swoich”, ale też - jak wnioskował Wiśniowiecki - magnat nigdy nie zapomniał, że zawarł związek małżeński „przecie nic po niej nie wziąwszy”24. Kłopotliwe kwestie majątkowe jedynie pogłębiały rozdźwięk między małżonkami. Uzupełniając treści nakreślone w recenzowanym wydaniu, warto dodać, że ostatecznie związek zakończył się rozwodem, a w 1722 r. Urszula Katarzyna została żona Fryderyka Ludwika Wirtemberskiego.

W kontekście kontrowersji obyczajowych w materiale źródłowym przypomniane też zostało małżeństwo Aleksandra Michała Łaszcza (zm. 1720), kasztelana bełskiego, który wbrew woli Urszuli z Krasickich $1^{\circ}$ voto Modrzewskiej, $2^{\circ}$ voto Granowskiej, $3^{\circ}$ voto Lipskiej (zm. 1719) ${ }^{25}$ zdecydował się porwać i poślubić jej córkę Elżbietę $z$ Modrzewskich. Wiśniowiecki wspominał, że w 1702 r. - po siedmiu latach od tego zajścia - doszło do pojednania Urszuli z Krasickich i jej kłopotliwego zięcia ${ }^{26}$. Wspominając o problematycznym małżeństwie, Janusz Antoni nieco pomylił fakty, czego jednak nie udało się wychwycić i skorygować wydawcom źródła [s. 123]. Elżbieta była bowiem nie córka, lecz pasierbica Urszuli z Krasickich. Pochodziła ze związku poległego pod Wiedniem Andrzeja Modrzewskiego (zm. 1683) i jego pierwszej małżonki, o której jednak niewiele wiadomo ${ }^{27}$. Faktem jest jednak, że po śmierci Modrzewskiego to właśnie Urszula $z$ Krasickich wzięła na siebie trud wychowania i edukacji panny. Wskazane małżeństwo, przeprowadzone poprzez porwanie panny, rzeczywiście bezpośrednio dotknęło jej macochę $e^{28}$. Warto też dodać, że po śmierci Aleksandra Michała Łaszcza

\footnotetext{
23 Bożena Popiołek, Królowa bez korony, 53.

24 Janusz Antoni Wiśniowiecki, Ilias Polski, 118.

25 Autorzy edycji źródłowej pominęli fakt trzeciego małżeństwa Urszuli z Krasickich, por. Janusz Antoni Wiśniowiecki, Ilias Polski, 123.

26 Ibidem.

27 Jan Wimmer, „Modrzewski Andrzej”, w: PSB, t. 21, z. 3, (Wrocław: Zakład Narodowy im. Ossolińskich, 1976), 543-545.

28 Szerzej o ujęciu tego problemu w aspekcie prawnym zob. Anna Penkała, Przeciw prawu, tradycji i obyczajowi. Sprawy procesowe szlacheckich małżenstw $w$ księgach sądów grodz-
} 
w 1720 r. Elżbieta $z$ Modrzewskich wyszła za mąż powtórnie, tym razem za wojewodę lubelskiego Jana Tarłę (zm. 1750).

Sprawa kłopotliwego małżeństwa została też wyeksponowana przy okazji wspomnienia o Feliksie Kazimierzu Potockim (zm. 1702), kasztelanie krakowskim. Wiśniowiecki przypomniał o pierwszej żonie Potockiego - Krystynie z Lubomirskich (zm. 1699), której pochówek rodził wiele domysłów i dyskusji. Co ciekawe, sam Potocki miał powtarzać, że ciało małżonki, pomimo upływu kilku lat od pochówku, miało zostać nienaruszone. Janusz Antoni napisał nawet o Lubomirskiej, że była to „święta prawie matrona” 29 , a w jej bogobojnym życiu dopatrywano się przyczyny zaistniałego cudu ${ }^{30}$. Jeszcze więcej emocji budził jednak powtórny ożenek Feliksa Kazimierza. W wieku sześćdziesięciu lat poślubił on bowiem zaledwie szesnastoletnią Konstancję Różę $z$ Łosiów (zm. 1753). Małżeństwo, jak skomentował to autor dzieła, Potockiemu „nie dodało zdrowia" ${ }^{31}$, a sam magnat zmarł już w 1702 r.

Równie wielkie emocje budziło postępowanie majętnych pań, wdających się $\mathrm{w}$ relacje uczuciowe $\mathrm{z}$ przedstawicielami różnych rodzin szlacheckich. Do takich postaci należała Teresa $z$ Gosiewskich $1^{\circ}$ voto Słuszkowa, $2^{\circ}$ voto Sapieżyna (zm. 1708), córka Wincentego Korwina Gosiewskiego i Magdaleny z Konopackich. Wiśniowiecki pisał o Gosiewskiej jako o „pani wysokiego rozumu w publiczne się mieszajacca interesa"32. Nawiazywał też do relacji uczuciowych, jakie jeszcze za życia pierwszego męża utrzymywała z innymi mężczyznami. Wiele miejsca poświęcił przede wszystkim budowaniu przez nią relacji $z$ niejakim Leszczyńskim, generałem wielkopolskim ${ }^{33}$. Autorzy wydania niestety nie poczynili stosownego wyjaśnienia, że chodziło o związek Gosiewskiej z Rafałem Andrzejem Leszczyńskim (zm. 1703), starosta generalnym wielkopolskim i późniejszym podskarbim wielkim koronnym [s. 246]. Po śmierci hetmana polnego litewskiego Józefa Bogusława Słuszki (zm. 1701) starał się zresztą

kich $\mathrm{z}$ terenu województwa krakowskiego $w$ czasach saskich, (Kraków: Wydawnictwo Libron, 2017), 52-54.

29 Janusz Antoni Wiśniowiecki, Ilias Polski, 117.

30 Krystyna $z$ Lubomirskich była znana ze swego ascetycznego życia, zaangażowania na rzecz zakonu jezuitów, zob. Ludwik Grzebień et al. (opr.) Encyklopedia wiedzy o jezuitach na ziemiach Polski i Litwy 1564-1995, (Kraków: Wydawnictwo WAM, 1996), 327; Stanisław Załęski, Jezuici w Polsce, t. 4, cz. 4, (Kraków: Drukarnia Ludowa, 1905), 1591-1593.

31 Ibidem.

32 Janusz Antoni Wiśniowiecki, Ilias Polski, 246.

33 Ibidem, 246-247. 
bezskutecznie o małżeństwo $z$ wdowa. Ta jednak odrzuciła jego zaloty, decydujacc się na związek $z$ innym ze swych wcześniejszych kochanków, wojewodą wileńskim Kazimierzem Janem Sapiehą (zm. 1720).

Kilka wstawek umieszczonych w dziele odnosi się też do prywatnych relacji małżeńskich osób szczególnie wpływowych w Rzeczypospolitej. Przybliżając sytuację panującą w familii Lubomirskich, Janusz Antoni nie omieszkał wspomnieć o problemach małżeńskich marszałka wielkiego koronnego Józefa Karola Lubomirskiego (zm. 1702) i jego żony Teofili Ludwiki z Zasławskich-Ostrogskich. Relacje pary przez lata nie układały się najlepiej, a ustawiczne konflikty przypieczętowała separacja małżonków orzeczona w $1695 \mathrm{rr}^{34}$ Janusz Antoni Wiśniowiecki podawał, że Lubomirski od żony „dla amorów $z$ panną pewną oddalił się" 35 , przypominając tym samym romans marszałka z Zofia Korzeniowską. W komentarzu do źródła wydawcy nie wspomnieli jednak, że problemy w relacji małżeńskiej sięgały znacznie szerzej [s. 109]. Lubomirski prowadził bowiem niezwykle rozpustny tryb życia, lekkomyślnie szafując posiadanym majątkiem. To zaś przekładało się na liczne problemy majątkowe i wyraźnie niepokoiło Teofilę z Zasławskich-Ostrogskich, usiłująca wówczas sfinalizować związek swej córki Teresy ze wspomnianym wcześniej Karolem III Filipem Wittelsbachem ${ }^{36}$. Kwestie finansów i bezmyślnego trwonienia majątku stały się przyczyną długotrwałego konfliktu między zwaśnionymi małżonkami.

Pomimo zasugerowanych uzupełnien, oceniając recenzowaną pracę, należy docenić pracę wykonaną przez wydawców. W przeważającej większości czynione przez Wiśniowieckiego wstawki zostały bowiem opatrzone wyczerpującymi przypisami, w których autorzy nie tylko trafnie zidentyfikowali osoby wzmiankowane w tekście, ale też zadali sobie trud, aby nakreślić szeroki kontekst opisywanych wydarzeń. To zaś zdecydowanie ułatwia lekturę i odbiór recenzowanego wydania. $\mathrm{W}$ rezultacie otrzymaliśmy bardzo cenna pozycję, ujawniającą nowe fakty dotyczace wydarzen $z$ pierwszych lat osiemnastego stulecia. Prezentowana edycja źródłowa obejmuje bowiem przede wszystkim wartościowy materiał przydatny dla szerokiego grona badaczy.

Adam Przyboś, „Lubomirski Józef Karol”, 27.

Janusz Antoni Wiśniowiecki, Ilias Polski, 109.

36 Biblioteka Czartoryskich, rkps 2735/IV, Teofila z Zasławskich-Ostrogskich Lubomirska do Elżbiety z Lubomirskich Sieniawskiej, Kraków, 17.07.1700, 9. 


\section{Bibliografia}

\section{Źródla}

Archiwum Główne Akt Dawnych, Archiwum Warszawskie Radziwiłłów, dział V, nr 3129.

Biblioteka Czartoryskich, rkps 2735/IV.

Biblioteka Narodowa, SD W 1/2995, Testamentum cardinalis Radzieiowskii primatis Regni Poloniae et M.D. Lithuaniae datum Dantisci die 12 Octobris anno 1705.

\section{Materiały źródłowe wydane drukiem}

Wiśniowiecki, Janusz Antoni. Ilias Polski, Przemysław P. Romaniuk, Jacek Burdowicz-Nowicki (wyd.), (Warszawa: Wydawnictwo Neriton, 2018).

\section{Opracowania}

Anusik, Zbigniew, Stroynowski, Andrzej. „Radziwiłłowie w epoce saskiej. Zarys dziejów politycznych i majątkowych", Acta Universitatis Lodziensis. Folia Historica, nr 33, 1989, 29-58.

Augustyniak, Urszula. „Instrukcja Bogusława Radziwiłła dla opiekunów jego córki, Ludwiki Karoliny (Przyczynek do edukacji młodej ewangeliczki w końcu XVII wieku", Odrodzenie $i$ Reformacja $w$ Polsce. Materiały, t. 36, 1992, 215-235.

Bagińska, Elżbieta. „Spór o Ludwikę Karolinę Radziwiłłównę”, Białostocczyzna, nr 4/48, 1997, 3-14.

Flathe, Heinrich Theodor. „Lubomirska Ursula Katharina Fürstin von”, w: Allgemeine Deutsche Biographie, t. 19, (Leipzig: Duncker \& Humblot, 1884), 333-334.

Grzebien, Ludwik et al. (opr.). Encyklopedia wiedzy o jezuitach na ziemiach Polski i Litwy 1564-1995, (Kraków: Wydawnictwo WAM, 1996).

Helcel, Antoni Zygmunt. O dwukrotnem zamęzciu Xiężniczki Ludwiki Karoliny Radziwiłłownej $i$ wynikłych ztad w Polsce zamieszkach. Przyczynek do dziejów panowania Jana III, (Kraków, 1857).

Jankowski, Rafał. „Sprawa testamentów Anny z Chodorowskich Dolskiej z 1711 roku", Miscellanea Historico-Archivistica, t. 21, 2014, 273-282.

Kamieński, Andrzej. „Polityka brandenburska Jana III Sobieskiego”, Zeszyty Naukowe Uniwersytetu Jagiellońskiego. Prace Historyczne, nr 146, z. 2, 2019, 313-316.

Lange, Tadeusz W. „Maltański epizod księcia Hieronima Lubomirskiego", LIMES. Studia i Materiały z Dziejów Europy Środkowo-Wschodniej, nr 3-4, 2010-2011. 
Lesiński, Jerzy. „Spory o dobra neuburskie”, Miscellanea Historico-Archivistica, t. 4, 1996, 95-132.

Penkała, Anna. Przeciw prawu, tradycji i obyczajowi. Sprawy procesowe szlacheckich małżenstw $w$ księgach sadów grodzkich $z$ terenu województwa krakowskiego w czasach saskich, (Kraków: Wydawnictwo Libron, 2017).

Popiołek, Bożena. Kobiecy świat w czasach Augusta II. Studia nad mentalnościa kobiet $z$ kręgów szlacheckich, (Kraków: Wydawnictwo Naukowe Akademii Pedagogicznej im. KEN w Krakowie, 2003).

Popiołek, Bożena. Królowa bez korony. Studium z życia i działalności Elżbiety z Lubomirskich Sieniawskiej ok. 1669-1729, (Kraków: Wydawnictwo Naukowe Wyższej Szkoły Pedagogicznej, 1996).

Przyboś, Adam. „Lubomirski Józef Karol”, w: Polski Słownik Biograficzny, t. 18, (Wrocław: Zakład Narodowy im. Ossolińskich, 1973), 27.

Sajkowski, Alojzy. Staropolska miłość: $z$ dawnych listów i pamiętników, (Poznań: Wydawnictwo Poznańskie, 1981).

Schiemann, Theodor. „Luise Charlotte Radziwill, Markgräfin von Brandenburg", w: R. Hoser (red.), Forschungen zur Brandenburgischen und Preussischen Geschichte, Bd. 3, (Leipzig: De Gruyter, 1890), 125-168.

Słaby, Agnieszka. „Aby po śmierci jakowa trudność na potem nie zachodziła" - testament marszałkowej Anny z Chodorowskich 1 v. Wiśniowieckiej Dolskiej”, Klio. Czasopismo poświęcone dziejom Polski i powszechnym, t. 50, z. 3, 2019, 131-148.

Tarnowski, Stanisław. „Tajemnica roku 1688”, Rocznik Akademii Umiejętności, 1883, 233-251.

Wejnert, Aleksander. Szczegóły wyświecajace powody zerwania umów małżeńskich królewica Jakóba Sobieskiego z księżna Radziwiłłowa Brandenburgska, (Warszawa, 1855), [online] [dostęp: 24.07.2021]. Dostępny w World Wide Web: <https://polona.pl/item/szczegoly -wyswiecajace-powody-zerwania-umow-malzenskich-krolewica-jakoba-sobieskiego-Z,Njc4NzIOMDE/2/\#info:metadata>.

Wimmer, Jan. „Modrzewski Andrzej”, w: Polski Słownik Biograficzny, t. 21, z. 3, (Wrocław: Zakład Narodowy im. Ossolińskich, 1976), 543-545.

Wójcik, Zbigniew. Jan III Sobieski 1629-1696, (Warszawa: Państwowy Instytut Wydawniczy, 1983).

Załęski, Stanisław. Jezuici w Polsce, t. 4, cz. 4, (Kraków: Drukarnia Ludowa, 1905). 